\title{
African motherhood proverbs and worldview: A matriarchal perspective
}

\author{
Dominica Dipio \\ Professor \\ Makerere University \\ Kampala, Uganda \\ Email: dodipio@yahoo.com/dodipio@chuss.mak.ac.ug
}
Submitted: April 12, 2018 / Accepted: December 12, 2018 / Published: October 4, 2019

\begin{abstract}
The 'mother' is a distinct female category that is prevalent in African folklore and art forms. Her prominence is mostly related to her centrality in the family - the basic cell of society. Because of her indelible connection to the children, she is consequently at the centre of the economy and spirituality of the family/community. The body and soul of the family rests in the mother's hand. This large space she occupies is evident in proverbs and sayings about her role in African society. Using selected proverbs across Africa, this paper examines how life is organised around the mother even if Africa is, today, predominantly referred to as a patriarchal society. The theoretical thoughts of Africanist scholars like Cheik Anta Diop and If Amadiume, whose scholarships show traces of Africa's matriarchal and matrilineal pastbefore the force of patriarchy eroded them underpin my analysis. Folklore, and particularly proverbs are repositories of a community's memory that bear traces of older cultures that may still be discernible in contemporary culture. My analysis of proverbs as pointers to the matriarchal traces of African communities draws from Heide GoettnerAbendroth's research on matriarchal societies around the world. The research findings indicate that both from the perspective of proverbs, symbolic expressions of culture and observances from everyday lived experiences, Africa's matriarchal origin is undeniable.
\end{abstract}

Keywords: motherhood, African proverbs, African worldview, matriarchy, patriarchy 


\section{Introduction}

Scholars have conducted fascinating researches on proverbs from diverse angles: linguistic (Beck, 2005); ethnographic (Arewa \& Dundes, 1964); rhetorical, artistic and aesthetic (Yankah, 1986, 1989); gender and women perspectives (Kiyimba, 2005, Diabah \& Appiah Amfo, 2005), and others. All these researches point to how the proverb genre is a rich and inexhaustible field of research. This is partly because proverbs yield meaning in specific contexts. As an art form, proverbs are particularly celebrated in Africa not just because Africa is predominantly a non-literate culture as theorists like Ong suggest (1982, p. 11). There are, as Yamaha observes, other non-literate communities like the Australian Aborigines and American Indians, where proverb use is not as diffused. In Africa proverbs are employed for their functionality as much as for aesthetic reasons (Yamaha, 1989, p. 326), making Chinua Achebe's description of proverbs use among the Igbo as 'the palm oil with which words are eaten' an apt expression of this aesthetic function. In terms of definition, scholars are agreed about the essential qualities of proverbs being brevity and pithiness, wittiness and cleverness. But this, by no means, is a closed definition. Proverbs at times embed riddles, parables and anecdotes, although these genres exist in their own rights. Thus, proverbs are characteristically symbolic and allusive, making their contextual interpretation open-ended (Finnegan, 1970, 390 \& 441; Yankah, 1989). Within the cultural contexts of their usage, proverbs have come to be associated with the 'truth' and the sagacious. The categories of proverbs that interest me in this paper are those related to the specific category of womanhood called 'mother'. My selection is influenced by the thoughts of Africanist scholars who argue that Africa was a matriarchal and matrilineal society long before the force of patriarchy eroded it.

Folklore, and particularly proverbs are repositories of a community's memory that may bear the traces of an older culture that may have changed today. As such, proverbs gain traction because they are generally accepted as affirming commonly held beliefs, although some of these truths may be contestable and ambiguous (Mieder 2003). Although cultures are diverse, it is intriguing how women and particularly mothers are described in similar ways across culture (Schipper, 1991, p. 4). Scholars tend to emphasize how women, in folklore, are cast in negative light (Weinger et al, 2006; Kiyimba, 2005; Hussein, 2009). Others who use different lenses to challenge the binary and stereotypical interpretation of gender in African folktales came 
up with more ennobling conclusions about women's position in African community. Wulemat (2013) analysed folktales for evidence of male superiority and female inferiority but he found none of such evidence. Other scholars like Kabaji (2005) wrote about the complex and non-essential way gender is played in folktales. In this paper, I use Goettner-Abendroth's theory to explore the traces of matriarchy in the proverbs about women, particularly mothers. In its complexity, the category woman defies a single definition: she is a daughter, a sister, a wife, a mother, a mother-in-law, and a grandmother. In each of her diverse roles, she is positioned differently in the community, although there are some areas of overlap.

\section{Theoretical Framework}

My analysis of motherhood proverbs is situated in the theoretical thoughts of Afrocentric, gender and matriarchy scholars who question the application of 'received' and Eurocentric lenses in analysing African experiences. This is the perception that Africa is and has always been, en masse and un-problematically, under patriarchy. In his two-cradle theory, Diop argues that the world is divided into two cradles of civilisation: the patriarchal north whose origin is Greece (Europe) and the matriarchal south, source of human civilisation, originating from Africa (Egypt). Although most African communities are described as patriarchal today, traces and residues of the old matriarchy can be gleaned in African folklores like proverbs and other symbolic cultural practices. Scholars like Amaidume (1987), Oyewumi (1997) and Nzegwu (2006) have, using sociological and historical research, questioned the notion that patriarchy was the hegemonic order in the particular African communities they studied. Although the different genders have their roles, the relationship was not characterised by the dominance of one gender over the other, but rather mutuality. Their researches also point to the existence of a dual-sex system that emphasized complementarity rather than gender hierarchy. These observations form part of what Goettner-Abendroth (2012) describes as characteristic of matriarchal societies.

Goettner-Abendroth who has devoted the better of her scholarship in researching matriarchies around the world, provides the theoretical tools for identifying matriarchies and their traces in contemporary cultures. Using these characteristics, I locate the residues of matriarchy in the proverbs about women, particularly mothers. Although matriarchal 
institutions are not homogeneous in their structures, Goettner-Abendroth in the introductory chapter identifies the following recurrent features of matriarchies that are affirmed by feminist and matriarchy scholars like Vaughan's (2007) and Von Werlhof (2001).

1. A matriarchal structure is basically an extended family headed by a matriarch where lineage follows the mother's line, right back to the great ancestress - the founding woman. ${ }^{1}$

2. Inheritance, identity, wealth and politics are determined through and around the matri-clan. To this effect, the Kongo (Congo) have a proverb: 'A clan with female posterity cannot perish.'

3. The economic life of the community is in the hands of women, and the economy is largely agricultural; and property may also be passed from mother to children. Gardening, working the land to produce crops is central to matriarchal identity and spirituality.

4. Men, on behalf of the matriarch, engaged in external affairs - public relations or politics with outside communities. The man could be a son, a brother to the matriarch or a husband. This varies from one community to the other. ${ }^{2}$

5. As reproductive agents, women pay great attention to their sexuality, and the ritual initiation into womanhood is a significant transition for all females (see Tamale, 2005).

6. Generally, marriage is not institutionalised. This allows for flexible marriage arrangements where unsatisfactory relationships are easy to terminate. Bride-price payment is not part of matriarchal arrangement. Pride-price payment is typical of patriarchy with its emphasis on exchange value (Vaughan, 2007). In matri-local communities where children are raised in the mother's household, they may take her name as the family name. A woman also has greater agency in choosing her husband who comes to live in the matri-clan.

\footnotetext{
${ }^{1}$ Although in the Buganda foundational myth/legend the emphasis is put on Kintu as the founding father, and the Baganda refer to themselves as baana ba Kintu, and not as baana ba Nambi, my analysis of the key symbols in this narrative points to Nambi as the $\mathrm{f}$ ounding mother of matriarchal Buganda. The manner in which the marriage came about also corresponds with the principles laid out by Goettner-Abendroth.

${ }^{2}$ In the context of Buganda, ekisaakate cultural school that is promoted by the queen mother of Buganda to continue the specialised tradition of female education for adulthood is one such manifestation of the traces of matriarchal culture in contemporary society.
} 
Dipio, D./African motherhood proverbs and worldview: A matriarchal perspective

Fathers play minimum role in children upbringing, and at times a father's identity may not even be known; and yet there is no stigma attached to this because life is organised around the mother.

7. In most matriarchies, women's roles transcend their presidency over domestic and economic affairs: they also take charge of the spirituality of the community, especially officiating in rituals related to the fertility of Mother Earth (productivity of crops) and women's re-productivity which are linked.

8. The children have strong connection and allegiance to the matri-line. The maternal uncle and aunt occupy special place in the life of the nieces and the nephews.

9. There is usually clear separation of non-hierarchical power between men and women: a kind of dual-sex gender roles that emphasize complementarity. (Goettner-Abendroth 2012, p. xxvi)

10. Where clan chiefs are always male, it is the women who select them, and they can also remove them if they fail to play their role well. ${ }^{3}$

Goettner-Abendroth (2012, p. xvi) emphasises that matriarchy is not the opposite of patriarchy: it is not a 'rule by' or 'domination by mothers.' Coming from the Greek word 'arche', which means 'the beginning', matriarchy refers to 'the mothers from the beginning.' This can be in reference to both the beginning of life, and to 'the cultural fact that they also created the beginning of culture itself.' In this sense the word has nothing to do with the association of patriarchy with domination and control of the other gender. This is an important point to note in reference to the representation of the mother through proverbs. Goettner-Abendroth observes that, '[c] ontrary to this, by virtue of giving birth to the group, to the next generation, and therefore to society, mothers clearly are the beginning; in matriarchy they have no need to enforce it by domination.' (p. xvi) In the current predominantly patriarchal cultures, what remains of matriarchy are fragments, 'distorted by thick layers of historically recent interpretations.' (p. xix) However, these misinterpretations have not totally erased the traces

${ }^{3}$ To date among the Baganda, for instance, the daughters are responsible for choosing an heir if a father failed to name one among his sons. 
of the features of former matriarchies, let alone those that are still active in Africa. ${ }^{4}$ The oral traditions of a people (e.g. folktales and proverbs) are as significant pointers to Africans' matriarchy as historical and archaeological evidences. (p. xxi)

\section{Methodology}

I used qualitative methodology and matriarchal theoretical perspective to analyse about 300 proverbs from around Africa related to the images of women in proverbs. Cumulatively, the proverbs were the primary data I used to reach the conclusions in this research. Two hundred and twenty (220) of these were from secondary sources, mostly drawn from Schipper's (1991) Sources of Evil: African Proverbs and Sayings on Women; and 57 were from interviews I conducted on my research topic, 'Mother-centred Africa through the Lens of Folktales' ${ }^{5}$ I clustered the proverbs into subthemes to identify the connecting threads in the proverbs on womanhood in general and motherhood in particular. These were then subjected to close critical reading within specific cultural contexts to unearth new shades of meanings enshrouded in proverbs on motherhood as pointers to Africa's now invisible matriarchal past. Most of the proverbs in Schipper's collection show how women are as 'sources of evil'.

Using Goettner-Abendroth's tools of matriarchal analysis, the same proverbs yield fresh and empowering meanings about women and mothers who emerge to be at the centre of the society. ${ }^{6}$ In my analysis, I searched for traces of Africa's foundational matriarchal structure, particularly claimed by scholars like Diop (1963) and Goettner-Abendroth (2012, chapters 16, 17, 18). The conclusions derived from close reading and textual analysis of the proverbs. My subjective interpretation of the proverbs is framed within matriarchal and feminist lenses. The analysis is grouped under the following proverb clusters: on womanhood in general, on wifehood, on motherhood, on grand-motherhood, on mothers-in-law, and on traces of matriarchal culture in proverbs and contemporary culture.

\footnotetext{
${ }^{4}$ The Bantu in Central West and North Africa are among the ancient matriarchies in the continent. Traces of matriarchal organisation still exist in these regions. There are existing matriarchal communities like the Bemba and the Luapula in Zambia, the Chewa in Malawi. (see Goettner-Abendroth, chapters 16, 17 and 18).

${ }_{5}$ The data for this article is drawn from my Cambridge Africa Programme for Research Excellence (CAPREx) fellowship (2016-2017). I am grateful to CAPREx ALBORADA fund for the support.

${ }^{6}$ It was difficult to find proverbs on fatherhood that are equivalent to those on motherhood. The few proverbs about men relate to the community's perception of them as courageous warriors, hunters, and players in diplomacy in the public sphere. This reflection reinforces Goettner-Abendroth's definition of the identities of matriarchal societies outlined above.
} 


\section{Findings}

Below are the findings of the research.

\section{Womanhood Categories}

In Africa, the expected destiny of every female is to become a mother. Proverbs on womanhood show that in patriarchy, characterised by the 'exchange economy', females are perceived differently in the various stages of their lives. In the patriarchal gender hierarchy, a female is ranked below a man; and in the hierarchical category of womanhood, a wife is on the lowest ladder. The wife is a marginal insider-outsider whose position improves with longevity in the marital home. She occupies the complex place of being both inside and outside in both the patri and marital clans (see Amadiume, 1987; Nzegwu 2006). Her allegiance is to both sides of her identity. Yet, a wife an outsider - is also a potential mother. Her position and circumstances improve when she becomes a mother of grown sons (as the daughters, in many African communities, move out to become wives and mothers elsewhere). As a mother, especially of grown children the woman's identity as 'wife' associated with marginality - is diminished. She comes to be referred to as 'the mother of' so and so, as a respectful appellation. In this position and the one that follows - grandmother - she wields even greater respect. Often, proverbs on 'plain' womanhood are contradictory and mean, as they tend to separate the female from the mother. The following examples illustrate the point: 'A woman has no safe abode' (Lango/Uganda) is a proverb that points to her mobility and therefore non-dependability. But motherhood becomes a powerful tool for her to negotiate her stability in a home. Another example, 'Two women cannot brew porridge well' (Kigezi/Uganda) is a proverb that claims women rarely cooperate among themselves. But this claim is contradicted by the frequent reference to women as collaborative team players. Thus, one proverb may represent woman as central to the wellbeing of a functional family or community; another may depict her as a simpleton to be dismissed or at best tolerated. For example: 'A home that has a woman/wife can easily be identified/known' (Bagisu/Uganda); versus 'Women are like gourds: they cannot balance' (Gikuyu/Kenya). These are examples that show that the complex story about the woman cannot be told in a linear, homogeneous manner. It also alludes to the patriarchal voice behind most of the proverbs that try to manipulate and control the agency of the woman. 
While there are contradictions in society's generic perception of women, the same society unanimously regards the mother as great. The category 'girl or daughter' is positively distinct from the general pool of woman-folk. Proverbs about a daughter express how patriarchal society with its exchange principle values her. She is linked to the mother, the noble role model she is expected to follow. Like the mother, she is portrayed as a donor to the community. She lives to serve others. She is valued and protected as a source of wealth both for the family she will marry into and the patri-clan she leaves behind. In the past, it was the resources girls fetched, through dowry (in terms of cows) that made clans and communities rich. A father (patriarchy) ensured that a daughter got married off well. ${ }^{7}$ In Goettner-Abendroth's (2012) structural definition of matriarchy, she makes a distinction between patriarchy and matriarchy in terms of economy. She refers to matriarchal economy as a balanced economy where women distribute goods. This economic relation ensures mutuality as it is 'based on the circulation of gifts.' (p. xxvi) This principle is expressed in Vaughan's (2007) theory of matriarchy as 'gift economy'. It contrasts with the 'exchange economy' aligned to patriarchy and capitalism; where the 'gift principle' is marginalised in the interest of profitmaking. 'Mothering', usually done by women, is a prime example of gift giving behaviour. 'Mothering requires direct gift giving to children, however, and since mothering is usually socially assigned to women, many women practise the gift mode of distribution during the time they are caring for children, and continue to do so even when they are not (and often practise it even if they never have children).' On the other hand, 'Exchange competes with gift giving by capturing the abundance, channelling it into the hands of the few or wasting it, thus creating scarcity for the many. Gift giving, which is easy and delightful in abundance becomes difficult and even self-sacrificial in scarcity.' (p. 371) These observations of Vaughan are reflected in proverbs about daughters and mothers.

The proverbs portray a daughter as greatly valued for her service and endowment functions. The challenge comes when there is no son in the family. This is understandable in patrilineal communities where the continuity of the family depends on the male issue. But this is not the case in matrilineal communities where descent follows the mother's line - a female issue. ${ }^{8}$ This proverb, from the Woyo from Congo, underscores this link

${ }_{7}$ African folktales are replete with tales of how fathers worry because a daughter refuses to get married and rejects all the suitors who present themselves. The father then sets a test to choose a suitor for her.

${ }^{8}$ An example of matrilineal community is the Chewa, found in both Malawi and Zambia. The birth of a baby boy is 
between the girl child and the numerical growth of a community: 'A girl is a peanut seed: she enlarges the clan.' She is treasured as a potential mother. The multiplication of the clan, particularly in matrilineal communities, depends on the female stock. In the logic of patriarchy, she may be seen depreciatively, but patriarchy cannot deny that she 'brings forth' sons into the family, both as biological children and as sons-in-law. Some proverbs that show the community's attitude towards girls are: 'The girl child removes dirt/rubbish from eyes'(Bagisu/ Uganda); 'The mother of a daughter never lacks salt in the house' (Rwanda); and the Buganda proverb that portrays the girl-child as a gift to the community: 'A girl child is like a mutuba tree: those who profit did not plant it.'

\section{The Wife}

I find the category of proverbs about the wife controversial and the male point of view is more evident in them. The tone ranges from playfulness to meanness. Embedded in this tone is the fear of being unable to control and dominate the wife all the time. The wife is portrayed as a source of trouble, and yet a man cannot do without her. The good wife is expected to be a continuation of one's mother: serviceable and self-sacrificing. This is expressed in the Hausa proverb, 'Lacking a mother, one takes a wife.' Other examples are: 'Better a bad wife than an empty house' (Baule/Ivory Coast); 'A wife is like a blanket: cover yourself, it irritates you; cast it aside, you feel the cold' (Ashanti); 'A wife is like an old cooking pot: you don't let your friend keep it for you' (Baganda); and 'They marry a wife because of the child.' (Mamprusi/Burkina Faso)

Some proverbs represent wives as challengers of the status quo who assert their individuality and agency. They show women are diverse: there are those who can endure a brutal marriage and there are those who cannot. In the theory and practice of matriarchy marriage is seen as a convenient institution that is not necessarily permanent (Goettner-Abendroth, 2012, p. 389). When it becomes unsatisfactory, the contract ends without bad feelings. The proverbs reveal how wives have always resisted bad marriages. Two Baganda proverbs highlight this: 'She who says, "Oh misery!" will die in her married state; she who says, "I cannot bear it" will leave.' It is desirable for marriages to be permanent, but they do not have to, particularly announced by a female who ululates as she comes out of the hut; and that of a baby girl is announced as announcer enters the maternity hut. The gestures speak for themselves: the boy is an outsider, while the girl is an insider. In this structure, it is sad for a family not to give birth to females as this forebodes the death of the matriline (Interview with Edward Kanyike, 2017). This example shows that the supremacy of the male child is not a 'universal' standard in Africa. 
in matriarchal social structures. Two Baganda proverbs say: 'Your wife may flee you but she does not die'; and 'Your woman runs away, but she does not defame you'. In the African context, one of the most important values in marriage is the connections and relationships it creates beyond the two individuals involved. The above proverbs acknowledge that marriages do break. They also point to the woman as an autonomous individual, although it is often her membership to a family/clan that seems to be emphasized. A wife 'does not die' when she flees from a bad marriage. She could always return to her natal home. Also, marriage transcends the individuals directly involved in it. The revered relationship between in laws remains even when the marriage has ended. The woman who quits does not defame her 'husband' who may be the father of her children. The established connections cannot be ruined by the couple's grievances. The value of relationship and connectivity is higher.

When it comes to proverbs about the co-wife, she is portrayed as the spanner in the works in the triangular relationship with the husband and the other wife/wives. At one level, the co-wives are like colleagues who share and are united by their common situation of shared husband. Other times they are cutthroat competitors for the man's attention, and so may capitalise on their seniority and hierarchy as a form of privilege. Proverbs portray this position as sources of stress and insecurity in the family among the wives themselves, between the wives and their husbands, and among the children. Although the man is apparently the beneficiary in polygamous arrangements, the situation does not guarantee his own happiness. The cautionary proverbs on the stress of polygamy show how this practice was not meant to be a common choice for men. I highlight some proverbs that refer to the privileges associated with hierarchy in polygamous marriages: 'The first wife is like a mother' (Swahili/East Africa); 'The feet of the first wife do not walk in the dew of the morning grass.' (Fang, Cameroon/ Gabon); 'You, first wife speak; you second, be silent.' (Yaka/Congo) Some proverbs highlight the competition, lack of trust among the wives and the 'divide-and-rule' approach the husband may employ, such as: 'Beat the bad wife with a new one' (Nobiin/Sudan); 'You measure some flour for your co-wife and this flour makes your husband spend the night with her' (Rundi/Burundi); 'If you dance with your co-wife, don't close your eyelid' (Rundi/Burundi).

Some proverbs show that at times the wives realise their common lot and cooperate among themselves in order to 'survive'. Common proverbs in 
this regard are: 'If a wife sees the stick that beats her co-wife, she throws it into the wilds' (Yoruba, Mamprusi, Krio/Sierra Leone/Buganda); 'A woman delivers a baby with the help of her co-wife' (Lango/Uganda). The husband may bear the brunt of polygamy himself as seen in these cautionary proverbs: 'If you marry two, you will die all the younger' (Luba/Congo); 'Two wives, two pots of poison' (Gikuyu/Kenya); and 'A man who married many wives can stay hungry.' (Gikuyu) Despite these cautions, a man may still believe, 'A man with one wife is chief among the unmarried' (Baganda/ Uganda); or 'To have one wife is to be one-eyed.' (Luba/Congo) Proverbs on the above categories of womanhood contrast dramatically with those on motherhood, as discussed below.

\section{Motherhood}

In proverbs, motherhood is venerated and placed on the highest pedestal of society. As indicated in Goettner-Abendroth's (2012) theory, the hoe and the garden are important symbols of women's identity in matriarchies. There are several proverbs about motherhood that are related to farming and the earth as symbols of the mother's reproductive agency. Writing particularly about the Bemba Bantu in Zambia, she observes:

The hoe is used exclusively by women, and features prominently in their dances, as a cult object, and is also represented as jewellery. In their ancient art of raising food, there is a tradition of using wooden mortars and old-fashioned stone grinders. Myths tell that women invented plant cultivation; indeed, it is they who have, ever since the earliest imaginable times, been in charge of the production and processing of food, as well as distributing the finished product among the clan members. This makes them completely independent of men, who are, however, dependent upon them. (p. 368)

The connection between motherhood and food is evident in proverbs. In traditional Africa, for both females and males to qualify for parenthood, their ability to ensure food production for the family is crucial. Among the Baganda, the traces of matriarchy are evident in the foundational myth of Kintu (man) and Nambi (woman). Nambi, the daughter of God, lives in her patri-family in heaven (Ggulu) until on one of her recreational journeys to earth in the company of her brothers, she meets Kintu who lives with his only cow as a companion. She falls in love with him and desperately persuades her father to allow her come down to earth to marry Kintu. The reluctant father finally accepts her pleas on condition that Kintu, a mortal, 
passes a set of 'impossible' tests he sets for him to prove his worth before he can marry his daughter.

There are points in this story that correspond to the key issues Goettner-Abendroth identifies about matriarchies. It is Nambi who initiates and chooses her spouse, Kintu. (p. 456) As a principle agent, she relocates to Kintu's home on earth with a number of items that improve Kintu's quality of life: he had one cow and drunk its urine for water. Nambi comes with an agricultural civilisation characterised by the hoe. ${ }^{9}$ Nambi also comes with seeds/grains both for planting and feeding her chicken. In fact, millet is the foodstuff she forgets and goes back for. In the process, she meets her brother Walumbe - Death, whom she tries to evade on her earth-bound journey. This time, Walumbe grabs the opportunity to follow his sister down to earth, where he later becomes a menace to Nambi's family. The subtle point in the story is how Nambi meets her brother 'Death' in the course of executing her responsibility as a woman and food provider. In its pithiness to capture the worldview of the community, this foundational myth functions as a mega proverb that enshrines the matriarchal institution of the Baganda. The centrality of agriculture, food production and the symbol of the hoe in the ritual and everyday life of the community are indicators of archaic matriarchal societies (Goettner-Adendroth pp. 388-389). The common Baganda proverb that has been adapted to a popular song: 'I would rather marry an ugly woman who cultivates fields, produces children and welcomes visitors,' summarises this ethic of matriarchy. It affirms an explanation given by one of my interviewees on how women, agriculture, food production, and family unity are all linked among the Bamasaba in Uganda. A woman's productivity and industriousness is prized above her re-productivity. Particularly in the past, it was not easy for a lazy woman to find a husband:

Marriage was not just about love; it was about productivity. Productivity and re-productivity are intertwined in the logic of my culture. A woman cannot give birth to children whom she cannot feed.... We have a proverb that is often uttered when a stubborn child runs away from home, to emphasize the point that the woman, symbolised by food, is the uniting factor in a home. We say, 'The black pot will bring you back'. This is the mother's pot that has gotten black with cooking, serving and giving the family happiness. The mother is about food! (Interview with Wotsuna Khamalwa, 2016)

The central symbol of unity among the Bamasaba, a community founded by a matriarch but now operates on the principles of dominant

${ }^{9}$ To date, the hoe is a major symbol in a Muganda woman's identity. It is one of the most important items a woman takes to her marital home. The hoe is a primary tool of food production, and the woman is at the centre of this activity. 
Dipio, D./African motherhood proverbs and worldview: A matriarchal perspective

patriarchy, has imbalu - the male circumcision ritual - as the most important symbol of identity and unity in the community. The symbol is around the common knife, inyembe, which'crafts' boys into men. In this male dominant performance culture, the position women, especially mothers, occupy is that of caregivers (Dipio, 2011). The mother's way of bringing people together is through food and nurturing. In the midst of the dramatic masculine activities like war this proverb reminds the community not to forget the memory of the mother, associated with the essential and humanising values of care and love manifested through providing daily food for the family. Proverbs about motherhood and food abound in many African communities. The mother's body - the breast - features copiously among 'food' proverbs as seen in the following examples:

'The mother's breast cannot get leprosy' (Baganda); 'A mother's breast cannot be abandoned because of a wound' (Mboshi/Congo); 'The baby who refuses its mother's breast will never be fully grown' (Gikuyu); 'The breast of your mother is not to be forgotten' (Tonga/Zambia); 'Mother's breast' (Ma'di/Uganda). Among the Ma'di, this is the warmest appellation siblings call each other. It is an appeal to the kind of solidarity that cannot be matched with any other. Similarly, 'Mother's big eye' (Ma'di/Uganda) is used in reference to a mother's vision and wisdom in carefully rationing the family provisions to ensure that everyone is catered for according to their needs. It refers to that spare 'food' the mother keeps aside, and makes available to the family member most in need at a given time. The mother's eye is like a god-eye that misses nothing, so that she can appropriately intervene. In the proverb, 'Mother is millet bread,' (Ma'di/Uganda) she is likened to a staple, nutritious iron-rich food like millet. Where food provision is concerned, the family looks up to her as a 'wonder worker' even in hard times, as expressed in the Zimbabwean proverb, 'Things are to be tried, an old lady cooked stones and they produced soup.' This proverb suggests that one cannot be an effective mother without being creative and sacrificial, and this is what it means to be on the side of life.

\section{Mother as Homemaker}

The proverbs in this category show that 'home' is around the mother. She is associated with industry and multi-tasks effortlessly. A proverb like, 'A mother of twins does not lie on her side'(Mano, Liberia; Fulani/ Wolof, Senegal), as she must feed both children simultaneously expresses 
Dipio, D./Legon Journal of the Humanities Vol. 30.1 (2019)

this. Similarly, the Ivorian (Baule) proverb, 'The mother declares she is lying down, but her feet are outside' underlines the mother's perceived 'omnipresence' and direction in attending to many situations at once. This kind of multiplicity of the mother demands sacrifice from her - another of her essential qualities. She may lay down to rest as her body demands, but her mind must rove to plan the next course of action, just as the mother of twins who feeds her children simultaneously cannot afford to adopt a posture of sleep that neglects the other. She is perceived as always available to give the best of herself to the family. These proverbs express the predominant reality of the ultimate, everyday sacrifice the mother makes for the family's wellbeing.

I find it noteworthy that being a homemaker does not confine the mother to the domestic sphere. She is both at home and out in the market, engaged in businesses that support the family. Researches show the African woman as a breadwinner (see Clark, 2001; Schroeder, 2001; Lovett, 2001); just like the poetic description of the woman in the Book of Proverbs, (31:1031) in a social context that appears to be matriarchal. She is an industrious manufacturer of all that the family needs in fine linen and foods; she secures all the provisions for the family; she is a distributer of food for the family and beyond; she is a business woman who buys fields and earns from her vineyard; she is physically well-built and successful in business; as a hard worker, she represents the 'gift economy' of sharing with the needy and the poor; the education of her children is totally in her hands; her husband prospers in the city's public sphere because of her industry; her husband and children's job is to praise and honour her. In the world of this proverb, life in the community and the family is around the 'good' woman (mother). The man, in the anonymous location of the city is a beneficiary, just like the children. The economy of the family and the community is fully in the hand of the woman. Reading this proverb from the lens of matriarchy, the woman is the head of the family. Her story evokes the Yoruba proverb, 'A mother is gold, a father is a mirror.' The images of gold and mirror can be interpreted variously. Gold is a solid, incorruptible, and stable standard of wealth. All values are measured against its stability. This is mother, as the foundational base of society/family. Father is mirror. I don't want to speak about the fragility of a mirror in relation to gold. A mirror is a reflector. The mirror the father - is the reflector of the values of the community. He is relatively distant compared to the mother. He reflects the rule of the community; a symbol of the Lacanian principle of the Law - the 'dos' and 'don'ts' of 
Dipio, D./African motherhood proverbs and worldview: A matriarchal perspective

society. A Buganda proverb, 'An insolent child has only a mother' implies the disciplinarian 'law' of the father that complements the compassion of the mother towards the child. ${ }^{10}$

\section{Symbolic Traces of Matriarchy in Cultures}

Several proverbs affirm Anta Diop's and Goettner-Abendroth's argument that Africa was largely a matriarchal community. The paradigmatic structure of many communities still points to a matriarchal order where the mother and her brother play significant symbolic and ritual roles in the life of the children. An Arabic proverb, 'The boy, if he turn out poorly, belongs twothirds to his mother's brother,' is a pointer to the centrality of the matri-clan to the wellbeing of the children. This is typical of matriarchal societies where the mother's brother plays an important role in the formation of his sister's sons. Among the Baganda for instance, the people from the matri-clan are so honoured that a proverb says, 'Where your mother is born, you cannot call anyone a child.'Every male - even the youngest in the family line - is referred to by the honorific title, kojja (maternal uncle).The same principle applies to the Nilotic Ma'di where the mother's brother - adrwa- is referred to as 'one's god on earth'. As an extension of the mother, his authority over the children is binding, and nothing concerning the children happens without his knowledge and blessing. (Interview with Emilio Mondo, 2014) His dominant position is equivalent to the place occupied by the father's sister - the Ssenga - in Buganda. She is particularly responsible for the formation of her brother's daughters. The Arabic proverb, 'Take girls from the breasts of their fathers' sisters' fits well into the role of the Ssenga. (Also see Tamale, 2005) She is the representative of the values of her community, and she instructs the daughters to carry the banner of their community wherever they get married to. A well brought up girl, therefore, should emulate her aunt just as the boy models after his (maternal) uncle or at times his paternal grandfather.

\section{Transcendent/Sacred Nature of Mother}

For her multifaceted role as life-giver and sustainer, comprehensive educator, food provider and scapegoat of the family, society, at least symbolically, reciprocates the mother's sacrificial love by placing her memory on the highest pedestal. This high position of the mother is expressed in the

\footnotetext{
${ }^{10}$ That a mother's presence enhances the flavour for life is further expressed in the following proverbs: 'If your mother is not there, your bowels ache while eating' (Buganda); and 'When your mother dies, you will eat yam peels' (Ngbaka Central African Republic).
} 
matriarchal Chewa (Malawi) proverb, 'Mother is God number two'; and the Igbo one, 'Mother is supreme.' Her responsibility to her children transcends death as the Bakonzo proverb says, 'One who has given birth to children goes looking back,' and the Mongo/Congo say, 'A mother cannot die.' These proverbs that express the desire to immortalise the mother is uttered at her funeral. It is an appeal to the mother not to forget the children she has left behind. She must continue her role beyond the grave. ${ }^{11}$

The person of the mother is regarded sacred. Out of love and respect, a child is expected not to capitalise on the mother's shortcomings, as expressed in the Chewa proverb, 'Your mother is your mother. Don't look at your mother's short legs.' One must always come to her defence and prevent any harm threatening her. Two proverbs point to this: 'The madman, who throws a stone into a crowded market, forgets that his own mother could be hit by his madness'(Yoruba) and 'As idiotic as a child who beats his/her mother.' (Buganda) It is only an idiot who can dishonour sacred mother. The ideal mother-child relationship is characterised by mutuality of love and devotion. In her old age the child is expected to care for the mother as she did in the past. This reciprocity is expressed in the following proverbs: 'The old woman looks after the child to grow its teeth and the young one in turn looks after the old woman when she loses her teeth;' (Akan/Ghana, Ivory Coast) 'An aged cow suckles (the udder of) its offspring;' (Buganda)'The hide that served the mother to carry the child will serve the child to carry the mother;' (Mboshi/Congo) and 'He who takes anything to his mother never says it is too heavy.' (Buganda) A reverse behaviour from a child invites proverbs like, 'The child who bites the back of his mother will find no other willing to carry him.'(Yoruba)And yet sacrificial mother 'would [still]carry the child that bites'on her back (Yoruba, Ma'di); or even conceal the child's 'ugliness' in public. To this effect, the Baganda say, 'The mother of an ugly child keeps it on her back.' She would shield that child from ridicule and public shame. However, a mother's whip of tough love will not spare the child's back if need be. And so the Yoruba say, 'One without a mother should never get a sore on his back;' and the Swahili say, 'Who is not taught by his/her mother is taught by the world.' It is the plight of the child who did not take counsel from the mother, to be taught by the world. However, ultimately, it is the mother who bears the shame of having

\footnotetext{
"In many African folktales, like Njabala (Buganda), it is common for characters to invoke the spirit of a dead mother to intervene in their favour. In Nollywood Epic, sequences where a suffering daughter goes to the grave of her mother to cry for help are also recurrent. These express the perception of the mother as immortal and divine, just as the proverbs indicate.
} 
Dipio, D./African motherhood proverbs and worldview: A matriarchal perspective

a mal-educated child. It is a sign she 'failed' to bring it up. And so, Africans from diverse cultures say, 'A misbehaved child shames his/her mother.' (Bakonzo/Uganda)

In all these proverbs, the mother emerges as the symbol of the 'gift economy' scholars like Vaughan (2007), Von Werlhof (2001) and GoettnerAbendroth (2012) have consistently written about.It is her sacrifice and self-effacement that benefits the family. The proverbs present her as one who lives for others (the children), although there is no guarantee that her devotion will be reciprocated by her children (Lamb, 1997). Her selfeffacement is expressed in the proverb, 'The mother of the big he-goat has no horns.' (Gikuyu/Akamba/Buganda)

\section{Grandmother and Mother-in-Law}

In the mother category, the grandmother is portrayed as a figure of uncontested authority in Africa. If the mother is venerated, the place of the grandmother, as 'mother of mothers' is at the pinnacle of the pedestal. The mother, in the centre of the family, remains comparatively marginal in relation to the grandmother and the public sphere. The grandma attains greater respect both in the family and the community. Among the Baganda, she is simply referred to as jajja (elder/wise one). This honorific title is gender neutral. It refers to seniority and wisdom. It is the grandmother's authority, informed by wisdom garnered over the years that makes her uncontested and sought after. This same sagacity is celebrated in proverbs like the following: 'Everyone knows the old woman's name, yet everyone calls her great-grandmother;' (Mamprusi/Burkina Faso) 'Your grandmother has taught you this and you want to ask your mother?'(Baule/Ivory Coast) At this stage, her gender is no longer important. Indeed, in the public sphere, she is comparable to a wise man and she participates in the rituals of the sages of the community. As the Mamprusi say, 'The toothless old woman still chews kola nut;' and the Baganda add, 'A woman with withered breasts drinks beer like a man.' Portraying the old woman as one who should be in the public space discoursing wisdom, the Minyanka of Mali say, 'The old woman who must grind and cook cannot join in the evening chat.' It is not expected that an old woman should engage in domestic chores like grinding and cooking. At her age, she would have children, grandchildren, and daughters in law to relieve her of such chores. Her place would be at the chat around the evening fire or among the elder solving societal problems. 
Dipio, D./Legon Journal of the Humanities Vol. 30.1 (2019)

The proverb points to the occurrence of such unfortunate situations where an old woman may not have had children, or her children may have left her.

The category 'mother-in-law' presents intriguing proverbs. Unlike the relationship of familiarity with one's mother or the grandmother, the rapport with one's mother-in-law is often like walking a tight rope. This is a sensitively regulated relationship for the parties. It is characterized not just by respect, but also fear. There is something unpredictable, like a looming danger about it. It is as if the mother-in-law is there to fault the son- or daughter-in-law. The Bemba from Congo cautions a son-in-law thus: 'The mother-in-law shows you her buttock without shame; the shame is yours.' One is advised never to respond to an offensive provocation from a motherin-law in a like manner, although the propensity to respond is real, as she is not one's mother! ${ }^{12}$ A mother-in-law is among the most respected personalities in African culture. In some communities, especially among the Bantu, a certain respectful physical distance must be established between her and a son-in-law. The two are not supposed to share space in a faceto-face conversation or physical contact. They may speak to each other through an intermediary or behind a curtain. It is a relationship riddled with taboos. She is represented as a difficult person to please. Thus it becomes an achievement to attain the right relationship with a mother-in-law. Such persons would gladly announce: 'I have a wonderful relationship with my mother-in-law' as an exceptional experience. The careful line one must toe in relation to the mother in law is expressed thus: 'If you get along with your mother in law but not with your father in law, you have forgotten your being a son in law' (Minyanka/Mali); 'Better the glares of a foreigner than those of a mother in law' (Rundi/Burundi); 'The son in law who showed too much respect one day ran away with the fish' (Chewa, Malawi/ Mozambique); and 'This can only be said in secrecy, when your mother in law is a witch' (Buganda). The proverbs show that the relationship with the mother in law is a controversial one. She can either be a 'helper' or an 'antagonist.'

\section{Conclusion: Implications for the Future}

Overall there are many proverbs that focus on women than on men. In the proverbs on motherhood one can glean the traces of matriarchy and the existing matrifocal nature of African societies. Life and culture are organised

${ }^{12}$ In African folktales, it is Hare the Trickster who dares offend his mother-in-law by sneaking into her kitchen against the rules of hospitality, and reachingout to help himself with the food that was not meant for visitors. 
around the mother who is prized highest of the categories of womanhood. She represents the 'gift economy.' The proverbs portray her as a gift to the family and to community at large. She is associated with all things that enhance and add quality to life. Close analyses of the proverbs show the traces of matriarchy that Diop and Goettner-Adendroth have theorized.

In matriarchal society, women were in charge of the agricultural based economy. Many proverbs associate motherhood with food and wellbeing. In traditional Africa, the father was rarely in the family, as his services may be needed outside the home. Proverbs about men often refer to their public relations and diplomatic abilities as emissaries, or courageous warriors and hunters. This leaves the cultural sphere of the home as women's space. This corresponds with Goettner-Abendroth's theory of matriarchies outlined in this paper.

What are the implications of this for gender relations in contemporary society? In the first place, women's 'traditional' hold and supremacy in agriculture and food distribution needs to be acknowledged and supported. Women need to have full access to land as their ventures and activities are linked to the wellbeing of the family and community. Going by the memories of Africa's non-hierarchical matriarchal past under the dualsex arrangement, it could be easier to attain gender parity because this was Africa's past. As Amadiume notes, '[a]t no period in the history of the patriarchal cultures of Europe has motherhood been accorded the same status as the reverence it has had in African cultures.' (1987,p. 3) Some of the values from the past need to be activated to inform contemporary and future gender relations and policies. This also requires deep research into the past to know, in Chinua Achebe's words, 'where the rains began to beat us.' 


\section{References}

Adesina, O. J. (2010). Re-appropriating matrifocality: Endogeneity and African gender scholarship. African Sociological Review, 14(1), 2-19. Amadiume, I. (1987).Male daughters, female husbands: Gender and sex in an African society. London: Zed Books.

Arewa, O. \& Dundes, A. (1964). Proverbs and the ethnography of speaking folklore. American Anthropologist, 66(6), 70-85.

Beck, M. R. (2005). Texts on textiles: Proverbiality as characteristic of equivocal communication at the East African Coast (Swahili).Journal of African Cultural Studies 17, (2), 131-160.

Clark, G.(2001). Gender and profiteering: Ghana's market women as devoted mothers and "Human Vampire Bats." In D.L. Hodgson \& S.A. McCurdy (Eds.), "Wicked" women and the reconfiguration of gender in Africa (pp. 293-311). Heinemann.

Diabah, G. \& Appiah-Amfo, N.A. (2014). Caring supporters or daring usurpers? Representation of women in Akan proverbs. Discourse Society. DOI: 10.1177/0957926514541343.

Diop, C.A. (1963). The cultural unity of Black Africa. London: Karnak House.

Dipio, D. (2011). The cost and reward of manhood: The practice of Imbalu ritual among the Bagisu.' In J. Ogude, G. Musila and D. Ligaga (Eds.),Rethinking East African literary landscape (pp.303-325.) Trenton: Africa World Press.

Finnegan, R. (1970). Oral literature in Africa. Oxford: Clarendon Press.

Goettner-Abendroth, H. (2012). Matriarchal societies: Studies on indigenous cultures across the globe. [Trans. K. Smith]. New York: Peter Lang.

Hussein, M. J. (2009). A discursive representation of women in sample proverbs from Ethiopia, Sudan, and Kenya. Research in African Literatures 40(3), 96-108.

Kabaji S. E. (2005). The construction of gender through the narrative process of the African folktale: A case study of the Maragoli (Doctoral dissertation, University of South Africa). Retrieved fromhttp://etd. unisa.ac.za/ETD-db/available/etd-07052006-120336/unrestricted/ thesis.pdf

Kiyimba, A. (2005). Gendering social destiny in the proverbs of the Baganda: Reflections on boys and girls. Journal of African Cultural Studies 17 (2), 253-270. 
Dipio, D./African motherhood proverbs and worldview: A matriarchal perspective

Lamb, S. (1997). The beggared mother: Older women's narratives in West Bengal. Oral Tradition 12(1), 54-75.

Lovett, M. (2001). "She thinks she is like a man": Marriage and (de) constructing gender identity in Colonial Buha, Western Tanzania 1943-1960.In D.L. Hodgson \& S.A. McCurdy (Eds.), "Wicked” women and the reconfiguration of gender in Africa, (pp. 47-66). Heinemann. Mieder, W. (2003). "Good fences make good neighbours": History and significance of an ambiguous proverb. Folklore 114 (2), 155-179.

Nzegwu, N. (2006). Family matters: Feminist: Feminist concepts in African philosophy of culture. State University of New York Press.

Ong, W. (1982). Literacy and orality in our times. Oral and Traditional Literatures. Ed. Norman Simms. Hamilton, NZ: Outrigger Publishers. Oyewumi, O. (1997). The invention of women: Making an African sense of Western gender discourses. University of Minnesota Press.

Schipper, M. (1992). Sources of evil: African proverbs and sayings on women. Nairobi: Phoenix Publishers.

Schroeder, A. R. (2001). "Gone to their second husbands": Marital metaphors and conjugal contracts in the Gambia Female Garden Sector. In D.L. Hodgson \& S.A. McCurdy (Eds.), "Wicked" women and the reconfiguration of gender in Africa, (pp. 85-105). Heinemann.

Tamale, S. (2005). Eroticism, sensuality and "Women's Secrets" among the Baganda: A critical Analysis. Feminist Africa: Sexual Cultures (5), 9-36.

Vaughan, G. (2007). Women and the gift economy: A radically different worldview is possible. Toronto: Inanna Publications \& Education.

Weinger, S., Fonjong L., Fonchingong, C., \& Allen, R. 2006. Unmasking women's rivalry in Cameroonian folktales. Nordic Journal of African Studies 15(1), 16-26.

Werlhof, C. (2001). Losing faith in progress: Capitalist patriarchy as an “Alchemical System”. In V. Bennholdt-Thomson, N. Faraclas, \& C. Werlhof (Eds.).There is an alternative: Subsistence and worldwide resistance to corporate globalization, London: Zed Books.

Wulemat, A. O. (2013). The images of women in Yoruba folktales. International Journal of Humanities and Social Sciences 3(4), 138149.

Yankah, K. (1989). Proverbs: The Aesthetics of traditional communication. Research in African Literatures 20(3), 325-346.

. (1986). Proverb rhetoric and African judicial processes: The untold story. Journal of American Folklore 99(280-303). 